UDC 632.913.1

(C) 2016

Yu. Klechkovskyi, Doctor of Science in Agriculture

L. Cherney, Candidate of Science in Agriculture

Research station for grape and fruit culture quarantine IZR NAAN,

V. Yashchuk, Candidate of Science in Agriculture

Ministry of Ecology and Natural Resources of

Ukraine Ye. Hiamtsy

LLC «Fininvest»

\title{
MODERN PROBLEMS OF DECONTAMINATION OF QUARANTINABLE PRODUCTS IN UKRAINE
}

The purpose. To describe modern problems of decontamination of quarantinable products in Ukraine by methyl bromide. Methods. Analyticalbibliographic (collection, analysis, systematization of information). Results. Without alternative to methyl bromide there is an acute necessity of its use in Ukraine for quarantine handling and handling before transportation of controlled objects in the sphere of plant quarantine which can be used according to Montreal protocol on the matters blasting ozonosphere since 1987 (with additions). Conclusions. To solve the problem it is necessary to reregistrate methyl bromide and to use it for all controlled objects in sphere of plant quarantine.

Key words: fumigation, methyl bromide, phosphine, hazardous organisms, efficiency of decontamination.

In connection with continuously growing volume of imported agricultural products, active exchange of breeding seed and planting stock, as well as with increase of transport possibilities among the countries, there occurs a danger in introduction and spread of adventive kinds of phytophages to the territory of Ukraine.

The most effective way for preventing the spread of quarantine and other regulated harmful organisms among the countries (181 counties in total) which had signed and ratified the International Plant Quarantine and Protection Convention (further on referred to as Convention) is decontamination of exported and imported plant products which are regulated by the International Standards concerning phytosanitary measures of this interstate establishment and regional organizations on plant quarantine and protection. One of them is quarantine fumigation - the most widespread and effective method of decontamination of regulated products at present. Its main difference from all 
the other kinds of decontamination is in fastness of treatment within time span of product movement. The principle of quarantine fumigation is in the fact that a pesticide as a gas penetrates due to diffusion to contaminated plant products and stays in them for some time (different for each organism), thereby liquidation of regulated harmful organisms is achieved by $100 \%$.

At present rather many pesticides that have a fumigation effect are known, such as methyl bromide, cyanic hydrogen, carbon bisulphide, chloropicrin, methallylchloride, sulphuric oxyfluoride, phosphorous hydrogen (phosphine). But in the whole world only two are widely used - methyl bromide and phosphine.

Methyl bromide $\left(\mathrm{CH}_{3} \mathrm{Br}\right)$ was first synthesized as far back as in 1884 . As a fumigant for protection against storage pests, it was proposed in 1932 in France and later in the USA. Since that time it was widely used for quarantine decontamination for plant products. The physical and chemical properties of this preparation, in particular, rather low boiling temperature, sufficiently large molecular mass and high vapor pressure in connection with high toxicity for all stages of pest development without making harm to plants themselves give grounds for its referring to a general-purpose fumigant which improves rapidly contaminated regulated products. Chemically pure methyl bromide is a colorless, odorless gas. Its molar mass is 94.94 . It boils at temperature of $3.6-$ $4.0^{\circ} \mathrm{C}$, freezes at $93^{\circ} \mathrm{C}$ below zero. Its specific gravity at temperature of $0^{\circ} \mathrm{C}$ : for liquid -1.732 and for gas -3.7 . Methyl bromide is referred to a group of nonflammable fumigants. Its solubility in water does not exceed $1.34 \%$ at $25^{\circ}$ $\mathrm{C}$, which allows to decontaminate alive plants, fresh fruit, vegetables and different plant stocks even those that have high moisture. As for its toxic effect on pests, it is referred to a group of chemical agents that paralyze the nervous system. It is ideal for killing mosquitoes and mites at all stages of their development and for any form of their contamination of plant and animal products, tares, warehouses, as well as for sanitary disinfection and deratization of living premises $[8,10]$.

For a long time the methyl bromide has been used in the whole world as the main 
of the Montreal Protocol, methyl bromide was considered as a substance that depletes the Ozone Layer. Ukraine as well as other countries has signed this document that appeals inter alia to restrict use of methyl bromide as the gas that depletes the Ozone Layer of the Earth. According to the schedule of stepby step curtailment within the frame of the Montreal Protocol program for substances that deplete the Ozone Layer (further on referred to as Protocol), it was prescribed to stop using methyl bromide completely in 2015 in industrial and production spheres. But in compliance with Art. $2 \mathrm{H}$, para. 6 of this Protocol, it does not relate to volume of its use for quarantine treatment and treatment before transporting plant and animal products. So, the Protocol itself excludes a possibility to stop using methyl bromide as a pesticide for quarantine decontamination of regulated cargoes before finding an alternative to it, which will meet requirements to its technological qualities and actual consumer values.

At the present stage such countries as Australia, Brazil, Vietnam, Israel, India, Iran, Canada, China, Korea, Malaysia, Mexica, Russia, Singapore, the USA, the Philippines, and Japan widely apply this fumigant, thus, giving preference in quarantine treatment and treatment of the cargoes before their shipping to it, but not to phosphine.

Moreover, it is worth stating that according to the International standard on phytosanitary measures ISPM No. 15, it was suggested that methyl bromide should be used for fumigation of wooden packing material, and there were not found any alternative chemical substances to it [11].

Basing upon these facts, in 2012 in Ukraine there was registered an insecticide methyl bromide for use as a fumigant in the agricultural industrial sector and in woodworking industry for treatment of timber, tare, sprigs and planting stock against quarantine pests. At the present moment this pesticide is under re-registration. This is a good action, but it is necessary to spread the area of its use to all the objects of regulation in the phytosanitary sector. This is the segment that is not served nowadays. And it is one of the terms of the phytosanitary safety of the country. The quarantine treatment of contaminated imported and exported goods is stipulated by the requirements of the said above Convention, in compliance with which the national phytosanitary services 
are obliged to use decontaminated regulated products in the interests of safety of the countries that have signed it. It is necessary to recognize the fact that in meeting the said requirements, the plant quarantine service of Ukraine is put to a difficult situation. To tell the truth, decontamination of the quarantine products is done by means of another fumigant - phosphine which can be applied only for fumigation of grain products, cereals, tobacco and warehouses. For decontamination of other varieties of plants it is not effective, so the results of fumigation are poor, which is not acceptable for quarantine decontamination. Really, some subjects of business made trials to register phosphine for contamination of wood and timber, but it was done rather due to their incompetence. Nowadays not a single country has registered this pesticide for its use for fumigation. Certainly, as regards this, some tests were carried out, but they did not give appropriate results.

Hydrogen phosphide or phosphine (PH3) for the past years as a fumigant has achieved a worldwide recognition in fumigation practice for cereals, tobacco, warehouses. It was first used for fumigation in 1934. Its high fire danger restricted its use, until in 1953 in Germany there was elaborated a form of fumigant use as aluminium phosphide tablets which evolve phosphine as gas under the effect of wet air or products. Later on in addition to aluminum phosphate, a magnesium phosphide was used. Phosphine is 1.6 times as heavy as air, its boiling point is $87.4^{\circ} \mathrm{C}$ below zero and the freezing point is $133.5^{\circ} \mathrm{C}$ below zero. The latent heat of evaporation is $102.6 \mathrm{cal} / \mathrm{gr}$, the lower limit of explosiveness is $-1.79 \%$ in air volume, it reminds odour of carbide [8, 10].

What does it make methyl bromide to be more attractive in comparison with phosphine? It was said above that methyl bromide acts actively on all phases of mosquito development. Thus, cereal mites have a phase of so called hypopus a phase that is very stable to fumigants. The same is referred to harmful quarantine grain and grain pest - kharpa beetle (Trogoderma granarium Everts), the harm of which was registered for more than 60 varieties of different products and which is able to damage up to $70 \%$ of products that are kept in the grain elevators and warehouses. Only methyl bromide guarantees complete 
killing of passive larvae and eggs of this phytophage [8]. Methyl bromide kills pests in fresh fruit and vegetables, flowers cut, in garden materials for 2-5 hours, in trees - for $16-24$ hours and in grain - for $24-48$ hours. At the same time, phosphine requires 8 days for killing cereal mites in flour, 10 days in grain at temperature above $15^{\circ} \mathrm{C}$ [12]. For fresh vegetables and fruit treatment with phosphine is problematic in general.

There were many discussions concerning toxicity of methyl bromide for treated plant products. In the process of fumigation it chemically binds with proteins and forms so called bromides. But according to data of Canadian toxicologist H.A. Monro (1962) it is known that quantity of residues (bromides) that are dangerous for humans is rather small. For instance, for receiving a therapeutic dose (a dose that will require medical interference) of bromides from decontaminated apples it will be necessary to eat more than $130 \mathrm{~kg}$ for one time [7].

Preference of methyl bromide is also in its ability to keep toxic characteristics at low temperatures which is very important in case of timber fumigation in autumn- winter period of time. It is very effective in high concentrations and short time of exposure. It has a very high degree of penetration not only in coniferous trees, but in hard-leaved species as well (it kills oak wilt pathogenic agent Ceratocystis fagacearum).

It is necessary to mention that at present we have a problem related to a lack of effective fumigants which can be used against harmful quarantine pests of Solanaceae and citrus cultures.

And methyl bromide has a wide range of agricultural use. As far back as the 80-s the Central Research Laboratory for Plant Quarantine headed by Ya.B. Mordkovych elaborated fumigation regimes against many phytophages of fruit products - Mediterranean fruit fly (Ceratitis capitata Wied), peach moth (Carposina niponensis Wals), oriental peach moth (Grapholitha molesta Busck), Japanese beetle (Popillia japonica New), vegetable produce - South-American tomato moth (Tuta abcoluta Mayr), potato tuber moth (Phthorimaea operculella Zell), timber insects - pinaceous secondary insects (Bursaphelenchus xylophilus), alternating sawyer (Monochamus alternatys Hope), planting stock - 
phylloxera (Viteus vitifoliae Fitch), alive plant pests - occidental European thrips (Frankliniella occidentalis Per.), palm thrips (Thripspalmi Kar.) and many others. These regimes are explained in instructions, they show high efficacy of methyl bromide which is depicted in achieved $100 \%$ death of phytophages for short exposure [2, 3, 4].

Moreover, for reduction of the negative action of the fumigant the specialists use methyl bromide in a mixture with carbon dioxide. It allows to reduce the rate of methyl bromide consumption by $40-50 \%$ due to a synergetic effect, as a result of which the phytotoxic affect onto the planting stock, fruit and vegetables and gas emission to the atmosphere is reduced [6]. Thus, in case of decontamination with gas mixture for fruit- decorative planting stock against California scale and that for grape planting stock against phylloxera, also with reduced rate of consumption, survival ability of plants was increased by $8-12 \%$, along with reduction of consumption. The grape nursery plants had increased moisture content, the length of growth and the diameter of a one-year vine [9].

In its turn, phosphine, in spite of utility in work and its positive characteristics in product treatment in ship holds for the time of cruise, carrying out cereal fumigation in vans-cereal carriers while running, is accompanied by a number of disadvantages and unpleasant consequences in use. This is presence of toxic residues in cereals and flour, a necessity to move the cereals for introduction of tablets that generate phosphine, prolonged action of exposure and degassing, as well as higher fire danger of the preparation.

In addition, fumigation of timber, fruit, vegetables and planting stock by means of preparations based on $\mathrm{PH}_{3}$ revealed itself not effective which in its turn results in issue of notifications on non-conformity of phytosanitary measures to ISPM No. 13.

\section{Conclusions.}

In connection with the said above, there occurs a necessity in preparations of methyl bromide when carrying out quarantine fumigation and fumigation before shipping any export objects of regulation, i.e. timber, wooden packing material, planting stock, turf, beet pulp, nuts, as well as any imported - fresh and dried fruit and vegetables nuts, flowers - against regulated harmful 
organisms. Taking into consideration that nowadays there is no worth alternative to methyl bromide, it is necessary to fasten spreading of its use on the territory of Ukraine in the line of quarantine treatment and treatment of phytogenic cargoes before shipping, which would solve the problem of phytosanitary safety for not only our country, but for the countries with which we have trade relations. This is also necessary for saving existing economic relationship with the countries which supply phytogenic products as import and for coming off the practice of returning the products contaminated with regulated organisms.

\section{Bibliography}

1. Васютин А.С. Обеззараживания продукции: [монография] / А.С.

Васютин, Я.Б. Мордкович.

- Москва: Агрорус, 2012. - 108 с.

2. Временная инструкция по обеззараживанию свежих фрруктов косточковых и семечковых пород от американской белой бабочка, восточной плодожорки и персиковой плодожорки. Москва 1968. - 30 с.

3. Инструкция по обеззараживанию посадочного материала, плодовых, субтропических, орехоплодных культур, винограда, лесодекаративных пород и луковиц цветочных растений от карантинных и других опасных вредителей. - Москва, 1985. - 41 с.

4. Инструкция по обеззараживанию плодов цитрусовых от средиземноморской плодовой мухи методом фумигации бромистым метилом. - Москва, 1964. - 32 с.

5. Маркин А.К. Руководство по обеззараживанию методом фумигации от карантинных и других вредителей / А.К. Маркин, С.А. Мусаев, В.В. Шеффрер. - Ташкент: Узбекистан, 1974. - С. 35-52.

6. Маслов М.И. Основы карантинного обеззараживания / М.И. Маслов, У.Ш. Магомедов, Я.Б. Мордкович. - Воронеж «Научная книга». - 2007. - C. 35-54.

7. Мордкович Я.Б. Современные методы борьбы с карантинными вредителями продуктов запаса / Я.Б. Мордкович, С.Ю. Чекменев. Москва, 1989. - 56 с. 
8. Мордкович Я.Б. Камерная фумигация (методическое руководство) / Я.Б. Мордкович, Г.Г. Вашакмадзе. - Ростов-на-Дону: Изд. РГУ, 2001. C. 48-56.

9. МСФМ №15. Руководство по регулированию древесных упаковочных материалов в международной торговли, 2002. Rome, IPPS, FAO Режим доступу: http://www.rshn- kbr.ru/files/file/MSFM N 15.doc

10. Montreal protocol on substances that deplete the ozone layer. Report ofthe methyl bromide technical options committee. Reprinting: UNEP Nairobi, Ozone Secretariat, 1994. - 304 p. 